PACS 73.61.Le, 73.63.Bd

\author{
A. P. Chebanenko, L. M. Filevska, V. A. Smyntyna, N. S. Simanovich, V. S. Grinevych
}

Odessa I. I. Mechnikov National University, Dvoryanskaya str.,2, Odessa, 65082, Ukraine, e-mail:lfilevska@gmail.com

\title{
THE HUMIDITY AND STRUCTURING ADDITIVES INFLUENCE ON ELECTROPHYSICAL CHARACTERISTICS OF TIN DIOXIDE FILMS
}

\begin{abstract}
The structuring additive concentration and humidity influence on the electrophysical properties of tin dioxide films was studied. The growth of $\mathrm{SnO}_{2}$ films, interelectrode resistance with the growth of polyvinyl acetate concentration in the initial solution is due to the porosity increase caused by the PVA increase in the films under study. The section of dark current temperature dependence, in vacuum from $110^{\circ} \mathrm{C}$ with an activation energy $\sim 0.7 \mathrm{eV}$, is due to the water molecules desorption. The resistance decrease of tin dioxide films in a wet atmosphere due to the dissociative adsorption of water molecules on the $\mathrm{SnO}_{2}$ layers surfaces has been established.
\end{abstract}

\section{Introduction}

Tin dioxide, an n-type semiconductor with a band gap of about $3.6 \mathrm{eV}$ (at $300 \mathrm{~K}$ ), belongs to the group of "transparent conductive oxides" (PPO), together with compounds such as $\mathrm{ZnO}, \mathrm{In}_{2} \mathrm{O}_{3}$, $\mathrm{WO}_{3}$, etc. Thin films of this oxide are transparent in the visible and near-UV spectrum region and at the same time may have high electrical conductivity, which makes them enough promising and even necessary material for transparent electrodes of solar cells, flat monitors, LEDs. [1-3].

Nanostructuring of thin $\mathrm{SnO}_{2}$ films increases their porosity and, consequently, the effective area of their surface. Due to this, the conductivity of such films is particularly strongly affected by sorption processes occurring on their surface. As a result, many of the electrophysical properties of tin dioxide thin films prove to be highly sensitive to the film's interaction with various media, including gaseous and liquid media [4].

Many biological media, including various gases $\left(\mathrm{CO}, \mathrm{CO}_{2}, \mathrm{SO}_{2}, \mathrm{H}_{2} \mathrm{~S}\right.$, nitrogen oxides, oxygen, ozone, etc.), as well as liquids (with the presence of different ions) interacting with tin dioxide films surfaces also can cause changes in their electrical characteristics. This property of tin dioxide makes it to be one of the most popular materials for the environment monitoring and various biological environments diagnostics. The influence of atmospheric air humidity on the tin dioxide conduc- tivity should always be taken into account when using this material, both as a sensor and an electrode.

This work is intended to study the influence of both the humidity and of the structural additive amount in a fabrication solution on the electrophysical characteristics of tin dioxide films.

\section{The film's fabrication methods and ex-} periment

Thin films of nanostructured tin dioxide were obtained using polymer materials by the sol-gel method [5]. Bis-(acetylacetonato)dichlorotin (BADCT) was used as the tin precursor of tin dioxide [6]. Polyvinyl acetate (PVA) was used as a structuring polymer material. After coating the glass substrate by the initial solution, the samples were annealed to remove organic constituents and form a tin dioxide layer.

The registration of the electrophysical characteristics of $\mathrm{SnO}_{2}$ nanofilms is based on the standard fixation of the I-U characteristics (CVC) and the Dark Current Temperature Dependence (DCTD). Indium was used as the electrode material. It was thermally deposited on the surface of the films in a high vacuum in the form of two parallel strips. The distance between the electrodes was $2 \mathrm{~mm}$. 


\section{Results and discussion}

Figure 1 shows the current-voltage characteristics for two films with the same precursor content $(10 \%)$ and different PVA content, measured at room temperature in air. It can be noted that they are practically linear and only in the region of high voltages (more than $200 \mathrm{~V}$ ) there is a tendency to a superlinear exponential current-voltage dependence.



Fig. 1. The current-voltage characteristics of $\mathrm{SnO}_{2}$ samples with a precursor content of $10 \%$ and PVA of $1 \%$ - curve 1 , PVA $0.1 \%$ - curve 2 measured in $\operatorname{air}(\mathrm{T}=293 \mathrm{~K})$.

Such behavior of the CVC was described in [7] and is associated with a change in the barrier height at the grain boundaries and electron tunneling through surface states.

From the comparison of curves 1 and 2 (Fig.1), it is seen that the interelectrode resistance of the films increases with PVA concentration growth (calculated from curve $1, \mathrm{R}=1.2 \cdot 10^{9} \Omega$, calculated from curve $2, \mathrm{R}=4.3 \cdot 10^{8} \Omega$ ). This becomes understandable, if it is taken into acount that polyvinyl acetate used in the preparation of films by the sol-gel method, plays the role of an organic filler and decomposes during high-temperature annealing, and the products of its decomposition volatilize. This causes the porosity and the development of the resulting films surfaces, which are more manifested, the larger the concentration of PVA in the initial solution.

Curve 1, Fig. 2 shows the current-voltage characteristic of $\mathrm{SnO}_{2}$ film, measured at room temperature in air. The interelectrode resistance calculated from this CVC is $1.4 \cdot 10^{9} \mathrm{Ohm}$. Curve 2 depicts the current-voltage characteristic of the same $\mathrm{SnO}_{2}$ film measured in a vacuum after the film was heated to a temperature of $+150{ }^{\circ} \mathrm{C}$ and then cooled to room temperature in vacuum.

The interelectrode resistance calculated from it was $1.3 \cdot 10^{8} \mathrm{Ohm}$. Thus, heat treatment in vacuum causes the resistances reduce of $\mathrm{SnO}_{2}$ film by almost an order of magnitude. This is due to the fact that under normal conditions, the oxygen adsorbed on the surface of $\mathrm{SnO}_{2}$ film, captures electrons from the $\mathrm{SnO}_{2}$ conduction band which results in the formation of positive space charge layer in the near surface region and, as a consequence, the energy bands curvature is of the cut off type. Since the films under investigation are thin, this causes a noticeable increase in their resistance.

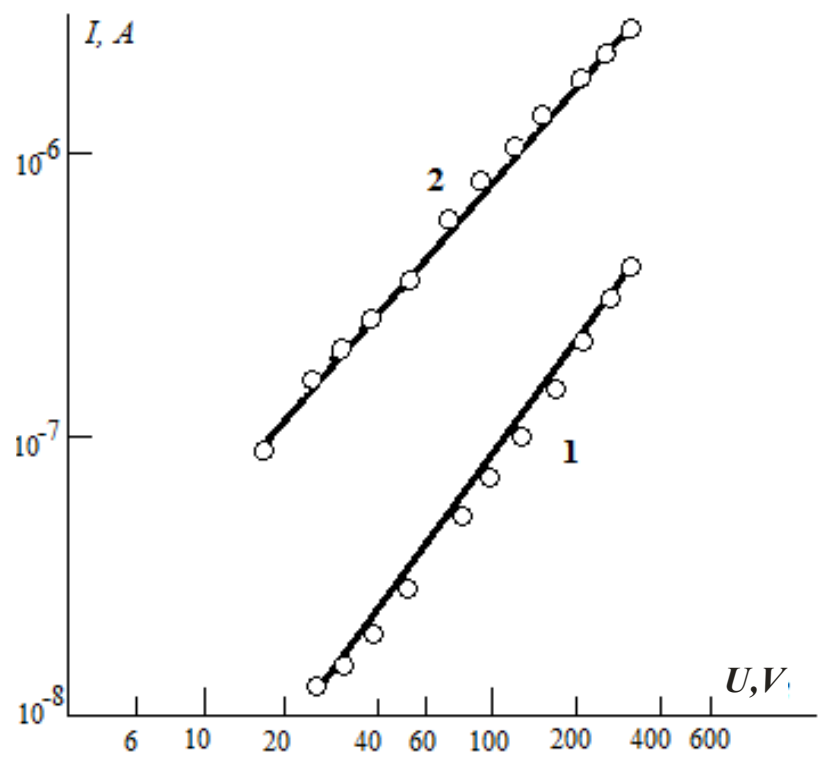

Fig. 2. The current-voltage characteristic of the sample $\mathrm{SnO}_{2}$ : curve 1 - in air, curve 2 - in vacuum. The precursor content is $10 \%$; PVA - 1\% $(T=293 \mathrm{~K})$.

The Dark Current Temperature Dependence (DCTD), measured in a vacuum, is of an activa- 
tion nature. That is, the current (and, hence, the electrical conductivity) increases with the temperature, obeying the exponential law (Fig. 3).

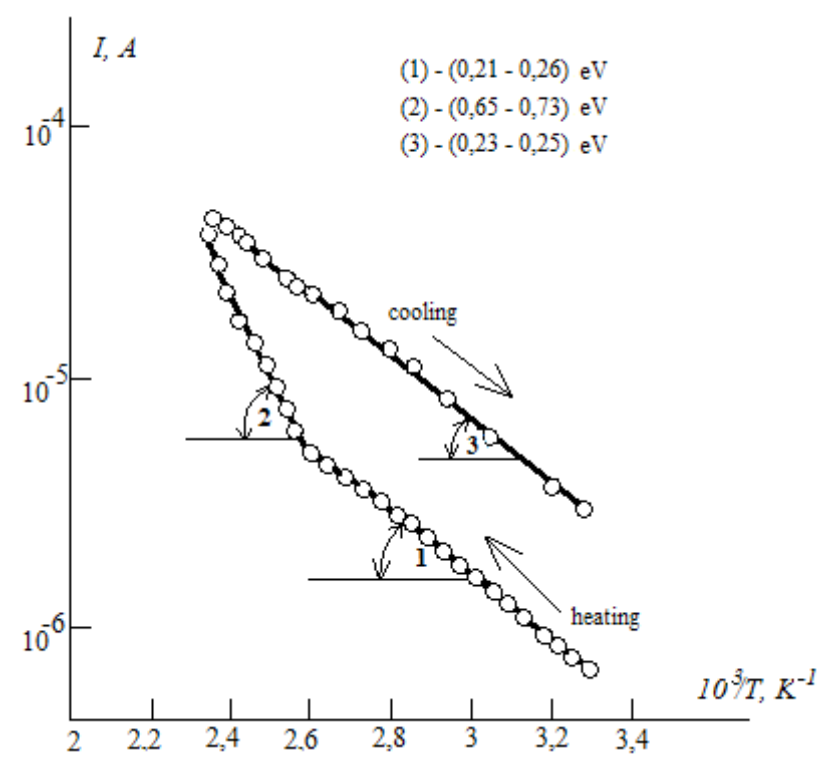

Fig. 3. The Dark Current Temperature Dependence of the film $\mathrm{SnO}_{2}$, measured in vacuum $(\mathrm{V}=500 \mathrm{~B})$.

As it can be seen from Fig. 3, during the heating process in the low-temperature region, the current flow is controlled by donor levels with ionization energy (0.21-0.26) eV. According to the published data, they are doubly ionized vacancies of oxygen $\mathrm{VO}^{++}$in the volume of $\mathrm{SnO}_{2}$ films $[8,9]$.

When the temperature of the sample (110-115) ${ }^{\circ} \mathrm{C}$ is reached, a sharp break is observed on the DCTD curve, and as the temperature increases further, the current grows with an activation energy $E_{a}=(0.65-0.73) \mathrm{eV}$. The similar values of the conduction activation energy $(0.72 \mathrm{eV})$ in the thin $\mathrm{SnO}_{2}$ films, were registered by the authors [10], but without interpretation the nature of the corresponding defects.

The mentioned region may be associated with the water molecules desorption from the surface of the $\mathrm{SnO}_{2}$ film.

The latter assumption is supported by the fact that the section with the indicated activation energy is absent on the DCTD curve measured during the cooling of the sample. On the DCTD curve, only the section with $\mathrm{E}_{\mathrm{a}}=(0.23-0.25) \mathrm{eV}$, associated with the oxygen vacancies in the film volume, is observed throughout the temperature range $[8,9]$.

The behavior of the DCTD curves measured in air (Fig. 4) in the temperature range up to +150 ${ }^{\circ} \mathrm{C}$ differs little from the DCTD curves measured in vacuum. However, in the region of higher temperatures $\left(150{ }^{\circ} \mathrm{C}\right.$ to $\left.220{ }^{\circ} \mathrm{C}\right)$, steep regions with an activation energy $(1.0 \pm 1.4) \mathrm{eV}$ appear on the dark current temperature dependence curves.

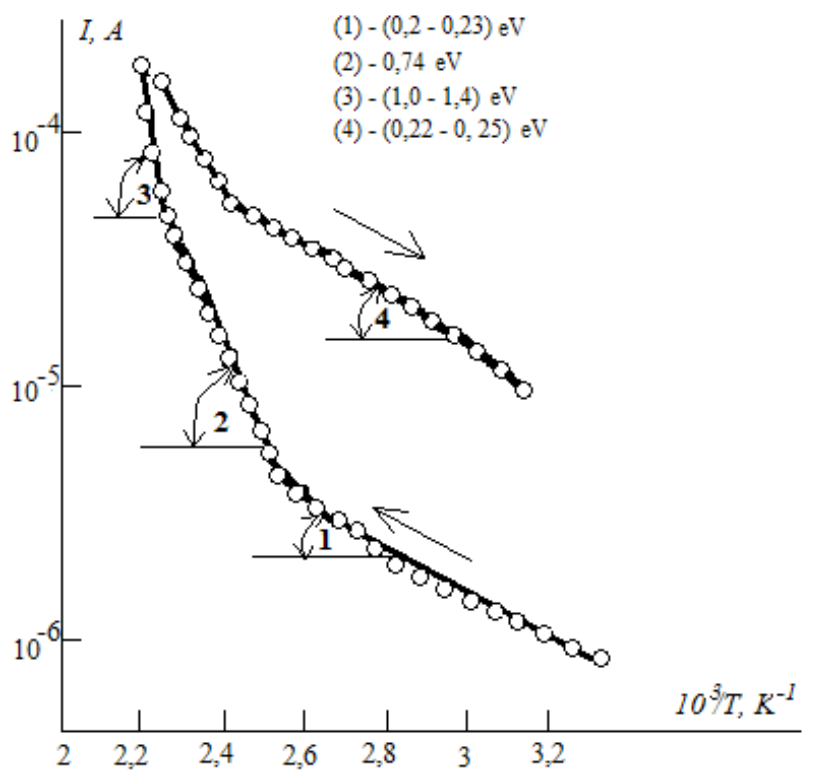

Fig. 4 The dark current temperature dependence of the $\mathrm{SnO}_{2}$ film, measured in air $(\mathrm{V}=500 \mathrm{~B})$.

Perhaps these areas are due to dissociative adsorption of water on the surface of the tin dioxide layers [11-13].

According to the literature, tin dioxide sensors exhibit gas-sensitive properties in the temperature region above $300{ }^{\circ} \mathrm{C}$ [13]. The operating temperatures for sensors based on thin (and, in particular, nanostructured) $\mathrm{SnO}_{2}$ films are much lower due to their porosity and the large effective surface area. The above given results of the Dark Current Temperature Dependencies make it possible to assume that these temperatures may be $(110 \pm 150){ }^{\circ} \mathrm{C}$ for the studied tin dioxide layers

Figure 5 shows the current-voltage characteristics of a $\mathrm{SnO}_{2}$ sample measured at a temperature of +130 oC in an atmosphere of dry air (curve 1), and in the presence of water vapor (curve 2). It can be stated, that the film resistance in the wet 
air atmosphere decreases several times as much. It is obvious, that a water vapor adsorbed on the tin dioxide surface leads to a resistance decrease.

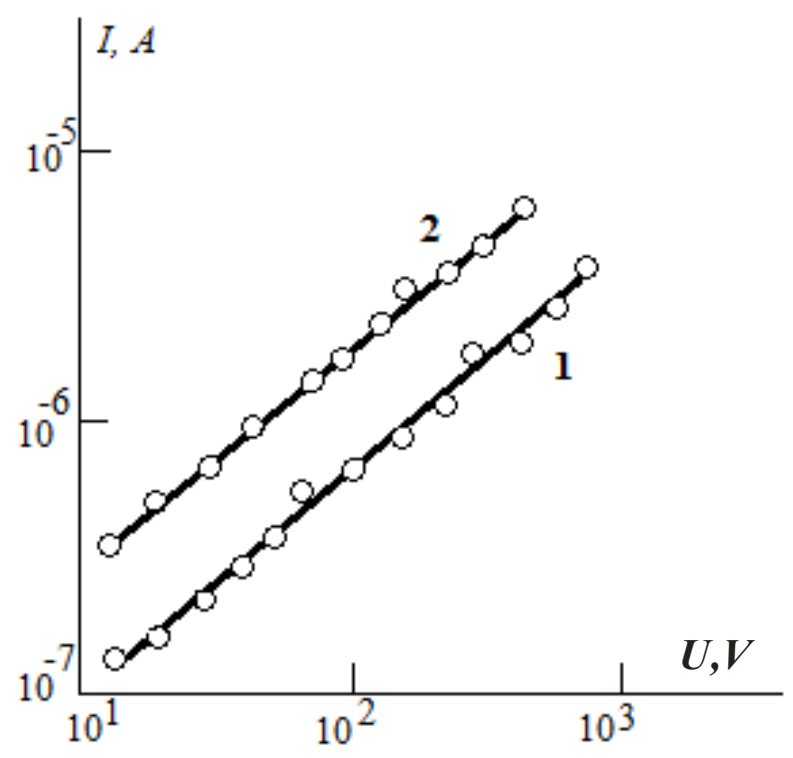

Fig. 5. The current-voltage characteristic of one of the $\mathrm{SnO}_{2}$ films, measured at the temperature $+130{ }^{\circ} \mathrm{C}$ in an atmosphere of dry air (1) and in the presence of water vapor (2).

At a high temperature on the $\mathrm{SnO}_{2}$ microcrystal surface, the water molecule dissociates into the hydroxyl group $\mathrm{OH}^{-}$and proton $\mathrm{H}^{+}$[14]. After the dissociation, the $\mathrm{OH}^{-}$group is localized on the surface atom of tin, giving the electron to the conduction band of the semiconductor. The proton $\mathrm{H}^{+}$is captured by the $\mathrm{O}^{-}$ion adsorbed on the surface, forming a neutral $\mathrm{OH}$ group. Thus, as a result of the adsorption process, the water molecules form two $\mathrm{OH}$ hydroxyl groups and hence the $\mathrm{O}^{-}$ion disappears. This leads to an increase in conductivity. As the humidity level grows, the conductivity should also grow, due to the increase in the dissociative adsorption of water molecules [11], which is observed in our studies.

\section{Conclusions}

Thus, the conducted studies of the influence of the structuring additives concentration and humidity on the electrophysical properties of tin di- oxide films made it possible to establish a number of corresponding features.

The increase in the interelectrode resistance of $\mathrm{SnO}_{2}$ films with the corresponding polyvinyl acetate concentration growth increasing in the initial solution is due to the growth of porosity of the films under study with an increase in the amount of PVA.

A fragment with an activation energy $\mathrm{E}_{\mathrm{a}}=$ (0.65-0.73) eV, apparently associated with the water molecules desorption, is observed on the DCTD curve measured in vacuum starting from (110-115) ${ }^{\circ} \mathrm{C}$.

A decrease in tin dioxide films resistance in a wet atmosphere due to the dissociative adsorption of water molecules on the surface of $\mathrm{SnO}_{2}$ layers has been established.

\section{References}

1. Granqvist, C.G. Transparent conductors as solar energy materials: A panoramic review. Sol. Energy Mat. Sol. Cells 2007, 91, 1529-1598.

2. Handbook of Transparent Conductors, Ginley, D., Hosono, H., Paine, D. C. (Eds.), Springer US, 2011

3. Hyung-Sik Woo, Chan Woong $\mathrm{Na}$ and Jong-Heun Lee, Design of Highly Selective Gas Sensors via Physicochemical Modification of Oxide Nanowires: Overview, Sensors 16, 1531 (2016); doi:10.3390/s16091531

4. M. Batzill, U. Diebold. Review: The surface and materials science of tin oxide Progress in Surface Science 79 (2005) 47-154

5. Filevskaya L.N., Smyntyna V.A., Grinevich V.S. Morphology of nanostructured $\mathrm{SnO}_{2}$ films prepared with polymers employment // Photoelectronics, 15, pp. 11-14 (2006).

6. B. Ulug, H.M. Türkdemir, A. Ulug, O. Büyükgüngör, M.B. Yücel, V.A. Smyntyna, V.S. Grinevich, L.N. Filevskaya. Structure, spectroscopic and thermal characterization of bis(acetylacetonato) dichlorotin(IV) synthesized in aqueous solution// Ukrainian chemical journal. - 
2010. - T. 76, №7. - C. 12-17.

7. Dhage S.R., Ravi V., Date S.K. Nonlinear

$\mathrm{I}-\mathrm{V}$ characteristics study of doped $\mathrm{SnO}_{2}$.

- Bulletin of Materials Science. 2004, 27(1), P.43-45.

8. Синёв И.В. Температурная зависимость сопротивления тонкоплёночных резисторов на основе диоксида олова. - Дисс., Саратов, 2014, с.209.

9. Fonstad C.G., Rediker R.H. Electrical properties of high quality stannic oxide crystals. - Journal of Applied Physics, 2003, Vol. 42, № 7, P. 2911-2918.

10. Kalinina M.V. et al. Temperature dependence of the resistivity for metal-oxide semiconductors based on tin dioxide. - Glass physics and chemistry, 2003, Vol. 29, № 4, P. 422-427.
11. Гаман В.И., Физика полупроводниковых газовых сенсоров, Томск, «Издательство НТЛ» 2012.

12. Алмаев А.В., Сергейченко Н.В., Рудов Ф.В. Влияние уровня влажности на характеристики сенсоров водорода на основе тонких плёнок $\mathrm{SnO}_{2}$. - Мат. $\mathrm{XX}$ Международной научно-практической конф., 2014, Томск, С. 315-317.

13. Рябцев С.В. Электрофизические и оптические свойства различных наноформ оксида олова: Автореф. канд. дисс., Воронеж, 2011, 32с.

14. Korotcenkov G., Brinzari V., Golovanov $\mathrm{V}$., et al. Kinetics of gas response to reducing gases of $\mathrm{SnO}_{2}$ films, deposited by spray pyrolysis // Sensors and Actuators. B. $-2004 .-$ V. 98 . - P. 41-45

This article has been received within April 2017

PACS 73.61.Le, 73.63.Bd

\author{
A. P. Chebanenko, L. M. Filevska, V. A. Smyntyna, N. S. Simanovich, V. S. Grinevych
}

\title{
THE HUMIDITY AND STRUCTURING ADDITIVES INFLUENCE ON ELECTROPHYSICAL CHARACTERISTICS OF TIN DIOXIDE FILMS
}

\section{Summary}

The structuring additive concentration and humidity influence on the electrophysical properties of tin dioxide films was studied. The growth of $\mathrm{SnO}_{2}$ films interelectrode resistance with the growth of polyvinyl acetate concentration in the initial solution is due to the porosity increase caused by the PVA increase in the films under study. The section of dark current temperature dependence, in vacuum from $110{ }^{\circ} \mathrm{C}$ with an activation energy $\sim 0.7 \mathrm{eV}$, is due to the water molecules desorption. The resistance decrease of tin dioxide films in a wet atmosphere due to the dissociative adsorption of water molecules on the $\mathrm{SnO}_{2}$ layers surfaces has been established.

Keywords: tin dioxide, thin films, humidity.

PACS 73.61.Le, 73.63.Bd

А. П. Чебаненко, Л. Н. Филевская, В. А. Смынтына, Н. С. Симанович, В. С. Гриневич

\section{ВЛИЯНИЕ ВЛАГИ И СТРУКТУРИРУЮЩЕЙ ДОБАВКИ НА ЭЛЕКТРОФИЗИЧЕСКИЕ ХАРАКТЕРИСТИКИ ПЛЕНОК ДИОКСИДА ОЛОВА}

\section{Резюме}

Исследовано влияние концентрации структурирующей добавки и влажности на электрофизические свойства пленок диоксида олова. Возрастание межэлектродного сопротивления пле- 
нок $\mathrm{SnO}_{2}$ при увеличении концентрации поливинилацетата в исходном растворе обусловлено увеличением пористости исследуемых пленок с ростом количества ПВА. Участок ТЗТТ, в вакууме от $110^{\circ} \mathrm{C}$ с энергией активации $\sim 0,7$ эВ обусловлен десорбцией молекул воды. Установлено снижение сопротивления пленок диоксида олова во влажной атмосфере, обусловленное диссоциативной адсорбцией молекул воды на поверхности слоев $\mathrm{SnO}_{2}$.

Ключевые слова: диоксид олова, тонкие пленки, влажность.

PACS 73.61.Le, 73.63.Bd

А. П. Чебаненко, Л. Н. Филевська, В. А. Сминтина, Н. С. Сіманович, В. С. Гріневич

\section{ВПЛИВ ВОЛОГИ І СТРУКТУРУЮЧОЇ ДОБАВКИ НА ЕЛЕКТРОФІЗИЧНІ ХАРАКТЕРИСТИКИ ПЛІВОК ДІОКСИДУ ОЛОВА}

\section{Резюме}

Досліджено вплив концентрації структуруючої добавки і вологості на електрофізичні властивості плівок діоксиду олова. Зростання межелектродного опору плівок $\mathrm{SnO}_{2}$ при збільшенні концентрації полівінілацетату в вихідному розчині обумовлено збільшенням пористості досліджуваних плівок із зростанням кількості ПВА. Ділянка ТЗТТ в вакуумі від $110{ }^{\circ} \mathrm{C}$ з енергією активації 0,7 еВ обумовлена десорбцією молекул води. Встановлено зниження опору плівок діоксиду олова у вологій атмосфері, обумовлене дисоциативною адсорбцією молекул води на поверхні шарів $\mathrm{SnO}_{2}$.

Ключові слова: діоксид олова, тонкі плівки, вологість. 